\title{
Effect of mineral and organic fertilization on soil micro- and macroaggregate stability in a long-term field experiment
}

\author{
Attila DUNAI - Zoltán TÓTH \\ University of Pannonia, Georgikon Faculty, Department of Crop production and Land Use, H-8360 Keszthely, \\ Deák F.u.16, dunai@georgikon.hu
}

Keywords: aggregate stability, mineral fertilization, organic fertilization, long-term field experiment

\section{Introduction}

Fertility of soils is influenced by many different factors; among them, agro-ecological attributes and basic soil characteristics are found as well. If we are examining in the crop production space, management enters to the factors which determine fertility. Different tillage and nutrient supplying methods, forms and volumes can influence soil fertility. Examination of these effects is one of the main investigated fields within agriculture; at the same time, partly- and non-revealed effects and interactions can be found in many sections as well. One of these important fields is the structure of soils. Knowledge of structure and especially the stability of the structure is crucial in terms of modern and sustainable crop production, since the extent of stability influences the conservation of favourable physical soil condition created by soil tillage for better water transport and indirectly soil biological processes (Siddiky et al., 2012). Therefore, aggregate stability has a great importance in agriculture, since better soil structure caused by higher aggregate stability resulted in increasing soil fertility (Peng et al., 2004). In our investigations, micro- and macroaggregate stability of soil was examined in a long-term field experiment to contribute the clarification of the role of different mineral fertilizer rates and complementary organic matter application to the aggregate stability of soil.

\section{Materials and methods}

In frame of the aggregate stability measurements a 36 years old organic manuring experiment was studied. The experiment has two factors. There are the complementary application of different forms of organic fertilizers and increasing rate of mineral $\mathrm{N}$ fertilization with a uniformly applied $100 \mathrm{~kg} \mathrm{ha}^{-1} \mathrm{P}_{2} \mathrm{O}_{5}$ and $\mathrm{K}_{2} \mathrm{O}$ fertilizer rates (even on the $\mathrm{N}$ control plots). The organic fertilizers have 3 different variants: no organic fertilizer application (control), farmyard manure (FYM) application (35 $\mathrm{t} \mathrm{ha}_{-1}$, in every third year before maize), straw (St) incorporation. After winter barley on the St plots an extra green manure (GM) is applied (Raphanus sativus var. Oleiformis) as a 2nd crop sowing on barley stubble. The $\mathrm{N}$ rates are 0-70-140-210-280 kg ha $(\mathrm{N} 0-\mathrm{N} 4)$ in case of maize. Samples were collected from the selected plots (N0-N2-N4) covered by maize during flowering in July 2017. During the investigations a Retsch AS200 Digit wet sieve series device were used including four sieves ( $2 \mathrm{~mm}, 1 \mathrm{~mm}, 0,25 \mathrm{~mm}$ and 0,053 $\mathrm{mm}$ ). The examinations were made with and without pre-wetting (either slow or fast wetting) as well. For statistical evaluation, ANOVA with Duncan post-hoc tests were performed.

\section{Results and discussion}

Without pre-wetting, the stability of $>2 \mathrm{~mm}$ fraction is depending on the nitrogen rate; in the plots without organic amendments significant stability decreasing can be found 
with the increase of $\mathrm{N}$-dose (Table 1.). $\mathrm{St}+\mathrm{GM}$ variants have lower decreasing. By the examination of 1-2 $\mathrm{mm}$ fraction, it is determinable that the highest stability values can be measured in the $\mathrm{N}$ control plots. However, the stability decreasing effect of the increasing $\mathrm{N}$-doses could be decreased by the FYM application also, but to a higher/lower extent compared to $\mathrm{St}+\mathrm{GM}$. In the $\mathrm{St}+\mathrm{GM}$ variants, the extent of decreasing is significant (more than $50 \%$ ). In case of $0.25-1 \mathrm{~mm}$ fraction, much higher stability values were measured. With pre-wetting, the stability of $>2 \mathrm{~mm}$ fraction was the highest in the control plots among the plots without organic fertilization amendments. With increasing of N-rates, the stability values were significantly decreased. In $\mathrm{St}+\mathrm{GM}$ plots, the highest aggregate stability was measured in control N0-plots. Opposite of this, in the FYM plots, the highest stability value was measured by the highest N4-dose. It should be highlighted that the stability was decreased significantly in NPK+St+GM N2 plots (70\%).

Table 1: Results of fractioned wet sieving with and without pre-wetting.

\begin{tabular}{|c|c|c|c|c|c|c|c|c|c|c|}
\hline & \multicolumn{2}{|c|}{$>2 \mathrm{~mm}$} & \multicolumn{2}{c|}{$1-2 \mathrm{~mm}$} & \multicolumn{2}{c|}{$0,25-1 \mathrm{~mm}$} & \multicolumn{2}{c|}{$0,053-0,25 \mathrm{~mm}$} & \multicolumn{2}{c|}{$<0,053 \mathrm{~mm}$} \\
\hline & WoPw & WPw & WoPw & WPw & WoPw & WPw & WoPw & WPw & WoPw & WPw \\
\hline NPK N0 & 4.34 & 17.19 & 4.29 & 9.77 & 37.63 & 25.48 & 22.7 & 13.3 & 5.95 & 10.66 \\
\hline NPK N2 & 5.26 & 15.51 & 4.03 & 11.99 & 30.67 & 27.1 & 23.08 & 15.11 & 10.13 & 11.26 \\
\hline NPK N4 & 1.85 & 9.48 & 2.12 & 10.29 & 26.18 & 28.83 & 32.21 & 17.41 & 6.32 & 8.63 \\
\hline NPK+FYM N0 & 3.16 & 16.17 & 5.25 & 11.06 & 33.53 & 26.29 & 26.41 & 14.55 & 5.96 & 9.63 \\
\hline NPK+FYM N2 & 6.11 & 13.31 & 4.92 & 9.08 & 35.36 & 29.22 & 21.07 & 14.6 & 6.09 & 11.24 \\
\hline NPK+FYM N4 & 3.1 & 18.81 & 4.55 & 12.55 & 39.82 & 26.71 & 22.88 & 12.69 & 3.07 & 9.97 \\
\hline $\begin{array}{c}\text { NPK+St+GM } \\
\text { N0 }\end{array}$ & 5.71 & 15.22 & 6.96 & 10.93 & 36.72 & 22.29 & 22.09 & 14.48 & 5.44 & 9 \\
\hline $\begin{array}{c}\text { NPK+St+GM } \\
\text { N2 }\end{array}$ & 5.41 & 4.56 & 4.61 & 5.75 & 39.49 & 31.2 & 23.11 & 16.74 & 2.65 & 14.4 \\
\hline $\begin{array}{c}\text { NPK+St+GM } \\
\text { N4 }\end{array}$ & 4.55 & 10.89 & 3.23 & 11.89 & 38.43 & 33.09 & 21.07 & 13.18 & 4.14 & 8.77 \\
\hline
\end{tabular}

WoPw: Without pre-wetting; WPw: With pre-wetting. Values are in $\mathrm{g} 100 \mathrm{~g}^{-1}$.

\section{Conclusions}

Based on the pre-wetting results, the stability values were higher in comparison to the fast wetting results in case of $>2 \mathrm{~mm}$ and 1-2 $\mathrm{mm}$ fractions. In case of pre-wetting measurements, stability of $>2 \mathrm{~mm}$ aggregates strongly depended on N-rate. In case of FYM application, the higher stability of $0,25-1 \mathrm{~mm}$ and $>2 \mathrm{~mm}$ fractions are significant.

\section{References}

Siddiky, M. R. K., Kohler, J., Cosme, M., Rillig, M. C., (2012): Soil biota effects on soil structure: interactions between arbuscular mycorrhizal fungal mycelium and collembola. Soil Biol. Biochem. 50. 33-39. https://doi. org/10.1016/j.soilbio.2012.03.001

Peng, X. H., Horn, R., Zhang, B., Zhao, Q. G., (2004): Mechanisms of soil vulnerability to compaction of homogenized and recompacted Ultisols. Soil and Tillage Research. 76. (2) 125-137. https://doi.org/10.1016/j. still.2003.09.006 